Journal of Development and Communication Studies, Vol. 8. No. 1, January -June, 2021 ISSN (Online \& Print): 2305-7432. http://www.devcomsjournalmw.org

\title{
An Analysis of the Entrepreneurial Ecosystem of Malawi: The Global Entrepreneurship Index (GEI) Approach
}

Frederick Pobee, Ph.D. candidate, Faculty of Business and Economics, University of Pécs, Hungary. Email: pobee.fred@gmail.com \& Thuso Mphela, Ph.D. candidate, Faculty of Business and Economics, University of Pécs, Hungary E Senior Lecturer, Faculty of Business, Department of Management, University of Botswana, Botswana. Email: mphelat@ub.ac.bw

\begin{abstract}
The research paper provides an in-depth analysis of the entrepreneurial ecosystem of Malawi. Employing the Global Entrepreneurship Index (GEI) methodology, the findings reveal a weak entrepreneurial ecosystem with a GEI score of 12.2 out of a possible 100. The relationship between the GDP per capita and the three entrepreneurship sub-indices, thus, attitude, ability, and aspiration are very weak and fall well below global average trends. Unfortunately, despite the high total entrepreneurship activities (TEA) in Malawi, this leads to little contribution to the country's GDP per-capita - a common phenomenon in many developing countries. At the pillar level, Malawi's performance is a mixed bag, however, with most pillars performing not only poorly but below world averages. Despite the general positive perception of entrepreneurship by citizens, the country's weak entrepreneurial ecosystem has failed to harness the propensity to develop new products and adopt new technologies for innovation and high growth entrepreneurship. From a policy intervention perspective, Malawi needs to focus most of its efforts and investments in five areas that include start-up skills, risk acceptance, high growth, risk capital, and human capital to improve the country's GEI score by 0.02 .
\end{abstract}

Keywords: Entrepreneurial ecosystem, Attitude, Aspiration, Abilities, GEI

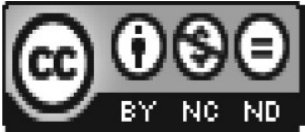

(C) 2020. The authors. This work is licensed under the Creative Commons Attribution 4.0 International License (CC-By-NC-ND). Users may freely share and redistribute this work provided that the author and the Journal of Development and Communication Studies are fully acknowledged. Users may not tweak or remix 
and offer this work for sale. The full

https://creativecommons.org/licenses/by-nc-nd/4.0/

license may be accessed at

To cite this article: Pobee, F. \& Mphela, T. (2021). An Analysis of the Entrepreneurial Ecosystem of Malawi: The Global Entrepreneurship Index (GEI) Approach, Journal of Development and Communication Studies, 8(1), 224 - 238 https://dx.doi.org/10.4314/jdcs.v8i1.11

\section{Introduction}

Entrepreneurial activities among countries have advanced significantly in recent years with notable contributions to economic growth (Van Stel et al., 2005). Overall, some have become successful while others are struggling to navigate the social, national, and international obstacles facing them. According to Audretsch et al. (2002), there are many factors including legal, institutional, social, and cultural that mould entrepreneurship. Entrepreneurs' success depends a lot on entrepreneurial ecosystems (Lafuente et al., 2018). The entrepreneurial ecosystem is a combination of stakeholders, formal and informal institutions, law, and regulation that impacts the entrepreneurial performance in a given country. More precisely, Acs et al. (2017, p.4) defined an entrepreneurial ecosystem as a "dynamic institutionally embedded interaction between entrepreneurial attitudes, abilities, and aspirations, by individuals, which drives the allocation of resources through the creation and operation of new ventures". According to Szerb and Trumbull (2018), the adoption of entrepreneurial ecosystems thinking acknowledges that the elements of the system are rather acting interconnectedly and not in isolation. Multi-stakeholders have each a significant role to play in ensuring the success of entrepreneurs. Unfortunately, unlike the more advanced countries such as the United States, Netherlands, Switzerland, and Canada with a high number of quality innovative and growthoriented entrepreneurial activities, most developing countries have a high rate of total early-stage entrepreneurial activities (TEA) which has minimal impact on economic development (Lafuente et al., 2018). Therefore, from a policy perspective, resources in developing countries may be allocated ineffectively resulting in diminishing returns. There is also evidence that the entrepreneurial ecosystem explains economic growth better than entrepreneurial activity. Therefore, Aljarwan et al. (2019) argue that a successful entrepreneurial ecosystem is an antecedent to economic growth and innovation. Findings by Ndala and Pelser (2019) suggest that $92 \%$ of the Malawian population is involved one way or the other in small and medium enterprises, this undoubtedly places entrepreneurship at the heart of the country's economy and a source of livelihoods. In this study, we investigate the entrepreneurial ecosystem of Malawi and the aim is to pinpoint the factors within the ecosystem that affect Malawian entrepreneurs, and also, to determine strengths and bottlenecks that enable or inhibit growth-oriented entrepreneurship in Malawi. The rest of the paper is 
arranged as follows. First, we discuss literature focusing on the key aspects of the GEI framework. Second, we present the methods adopted, chiefly discussing the GEI approach and a brief on the data used. Third, we present and discuss the results and contrast them with existing literature. The results will focus mainly on the bottlenecks of the country's entrepreneurial ecosystem. Following, conclusions are made to extract the meaning of results for Malawi at a macro level. Finally, we end by making policy recommendations and suggestions to address the bottlenecks.

\section{Literature Review}

Entrepreneurial ecosystems are heralded as a conducive vehicle to facilitate the transition of countries from entrepreneurship policy towards a policy for an entrepreneurial economy (Stam, 2015). This is done to reduce the quantity while increasing the quality of entrepreneurship. However, there is generally limited research on entrepreneurial ecosystems in Africa (Lafuente, Acs, and Szerb, 2018). This is particularly unfortunate considering the economic challenges faced by the continent, exacerbated by poor policies in general. Entrepreneurship is a multi-faceted phenomenon that occurs in environments comprising several stakeholders from private to public institutions and involving many interests that link continuously in a web called entrepreneurial ecosystems (Szerb et al., 2016). The Global Entrepreneurship Index (GEI) facilitates a holistic evaluation of these ecosystems (Szerb and Trumbull, 2018). Acs et al. (2017) contend that the GEI as a measure of entrepreneurship is more plausible than TEA especially when high growth orientation is the objective. Lafuente et al. (2018) support this argument by citing that Africa's high entrepreneurial activity (TEA) has not shown any significant impact on the GDP growth of many countries on the continent. Van Stel et al. (2005) found that entrepreneurial activity's impact on GDP growth depended on GDP per capita. For countries with low GDP per capita, entrepreneurship tends to have a negative effect on GDP growth. GEI's focus is on opportunity-driven as opposed to necessity-driven entrepreneurship. Entrepreneurship in Malawi generally faces challenges including but not limited to unavailability of proper functioning capital markets, poor labour markets, corruption, constrained raw material supply, and unsupportive government policy (Ndala and Pelser, 2019). Even though their study does not discuss entrepreneurial ecosystems per se, Ndala and Pelser express the desire to have coordinated efforts across the entrepreneurship development stakeholders.

\section{Entrepreneurial attitudes}

Attitude is a widely studied concept from organisational behaviour, to psychology, to medicine, to entrepreneurship. Perhaps, more established relationships between attitude and planned behaviour are often discussed under the Theory of Planned

Behaviour (TPB) (Passafaro \& Kosic, 2019). Attitude has been touted as one of the 
most important determinants of human behaviour and intentions. According to the Boston University School of Public Health, behavioural intentions are likely to be motivated by attitudes about the likelihood of certain behaviour/actions leading to expected consequences/outcomes. Earlier studies (e.g., Beugelsdijk \& Noorderhaven, 2004) have found entrepreneurial attitudes to be positively correlated to regional economic development. In Europe, Draghici, Albulescu \& Tamasila (2014) concluded that entrepreneurial attitude positively influences entrepreneurial activity. Both these studies made this conclusion at aggregated levels despite using different sets of data. However, entrepreneurial attitudes differ across regions and nations (Beugelsdijk \& Noorderhaven, 2004). And quite often there are inconsistencies in how attitude as a construct is defined and measured across different studies (Passafaro \& Kosic, 2019). Beugelsdijk \& Noorderhaven (2004) also make an interesting argument - that entrepreneurial attitude can act as both a driver for economic development and a product of economic development. The latter implies that attitude towards entrepreneurship may improve as economic prosperity increases and more entrepreneurs are attracted to new and growing opportunities. Fortunately, entrepreneurial attitude can be improved through training (Karlsson \& Moberg, 2013). Bullough \& Renko (2013) argue that for self-efficacy and entrepreneurial resilience to be developed, entrepreneurs and those aspiring need to attend development training, join entrepreneurial networks, and be actively involved in entrepreneurship pursuits. However, a higher entrepreneurial attitude doesn't always translate to higher entrepreneurial activities since there may be several factors that may hinder the smooth translation of this process (Bosma and Schutjens, 2011).

\section{Entrepreneurial abilities}

In Bullough \& Renko's (2013) view, entrepreneurs have many reasons to be discouraged. Entrepreneurial abilities, sometimes referred to as entrepreneurial selfefficacy (ESE) can be defined as "an individual's perceived competence in starting a business" (Karlsson \& Moberg, 2013). The perceived competence ignites selfconfidence and gives one confidence to initiate the entrepreneurial journey. Potential entrepreneurs assess their self-efficacy against available opportunities under prevailing conditions and based on these, decide to start a business (Bosma and Schutjens, 2011). Bullough \& Renko (2013) opine that entrepreneurial abilities are critical in the development of entrepreneurial aspirations. The authors argue that when entrepreneurs have very strong confidence in their abilities, it gives them the resilience to thrive in adversity and even exploit opportunities that are presented by adversity. A study in Nigeria by Jayeoba (2015) ranked university students (using mean scores) who intended to go into entrepreneurship higher on entrepreneurial abilities than those who had no intention or undecided. Räty (2019) found a positive 
correlation between student abilities like "innovativeness", "ambitiousness", "competitiveness" and "risk-taking" and entrepreneurial intentions in Finland.

\section{Entrepreneurial aspirations}

Aspiration is a critical component of life in general. From the day we are born, human beings start shaping desires and aspirations. One of the common questions we were asked when we started school was "what do you want to be when you grow up?" Specifically, one of the key questions entrepreneurship research seeks to answer is why people seek entrepreneurial opportunities. Several studies have used traits, utility maximisation, or career choice to answer this question. Lee \& Venkataraman (2006) used a comparison between aspiration vector (AV) and perceived market offering vector (P-MOV) to determine whether an individual will choose entrepreneurship on employment. They argue that if an individual's AV is greater than MOV they are likely to choose entrepreneurship. Both AV and MOV are multidimensional constructs made of economic, social, and psychological benefits that the individual wants or believes they can have, informed by their abilities and what the market offers at a certain point in time respectively. A study of Britain by Henley (2007) revealed that high levels of entrepreneurial aspirations do not always translate to higher start-up rates (this could be country or region-specific variations). However, policy can be used to ensure that those who aspire to be entrepreneurs can be nudged to advance beyond readiness. Research by Hessels, van Gelderen, \& Thurik, (2008) using GEM data from 26 countries concluded that entrepreneurs who are motivated by necessity or desire for independence are not necessarily ambitious and may not contribute significantly to the economy.

\section{Role of Policy and Governance in Entrepreneurship}

Stam (2015) notes that the transition from entrepreneurship policy to policy for entrepreneurial economies is underway in many countries. The environment and context within which entrepreneurship occurs, as far as they facilitate or impede its success are documented widely. For example, the "Doing Business" initiative by the World Bank focuses on regulatory reform with a view of improving the ease of doing business in respective countries. To give context, the Doing Business 2020 report ranks only 2 sub-Sahara African economies in the top 50 countries globally (World Bank, 2020). The report notes very slow progress in regulatory reforms in Africa. Strict regulations on business registration can discourage one to even think of starting a business (Bosma and Schutjens, 2011). For example, one of the factors that Doing Business considers in its ratings is how long it takes to register and establish a new business. Consequently, the more days it takes, the more deterring it is to entrepreneurial pursuits. 


\section{Methodology}

This study evaluates the Malawian entrepreneurial ecosystem using the Global Entrepreneurship Index (GEI) as proposed by Acs et al. (2017) and GEDI (2018) based on the Global Entrepreneurship Monitor (GEM) data. Thus, the country ecosystem is evaluated along the GEI's three sub-indices, namely, entrepreneurial attitudes; entrepreneurial abilities; and entrepreneurial aspirations. Entrepreneurial attitudes measure the extent of how a country feels about (perceives) entrepreneurship. Factors in this sub-index include opportunity recognition, start-up skills, risk perception, networking, and cultural supports of entrepreneurs. Furthermore, entrepreneurial ability refers to the capabilities of entrepreneurs that determine the degree to which new start-ups will have the potential for growth (Acs et al., 2017). These include opportunity start-up, technology absorption, human capital, and competition. The third sub-index is entrepreneurial aspirations, which according to Acs et al. (2017) refer to entrepreneurs' ambition on entrepreneurship. Pillars in this index include product innovation, process innovation, high growth, internationalisation, and risk capital. In total, the GEI model has 14 pillars that contain individual and institutional variables that correspond to the micro and macro-level entrepreneurship. To demonstrate the effect of interaction between pillars, GEI penalizes for bottlenecks. The weakest link or underperforming pillar would have a negative bearing on the score. However, due to the scarcity of national resources and the complex nature of reality, the GEI can't produce perfect indexes for all the 14 pillars. Hence, recommendations are made for countries with weaker performing pillars on how to strengthen these pillars.

\section{Results}

\section{Analysis and discussion of the entrepreneurial ecosystem of Malawi}

The results are presented in the following format. First, the building blocks of the Malawian entrepreneurial ecosystem are evaluated. Second, we assess the strengths and weaknesses of the Malawian entrepreneurial ecosystem.

Figure 1 below present's graphs plotting Malawi's GDP per capita against the three sub-indices; entrepreneurial attitude, entrepreneurial ability, and entrepreneurial aspiration, as well as the country GEI.

Figure 1: GDP per capita against the GEI scores and the sub-indices of Malawi 


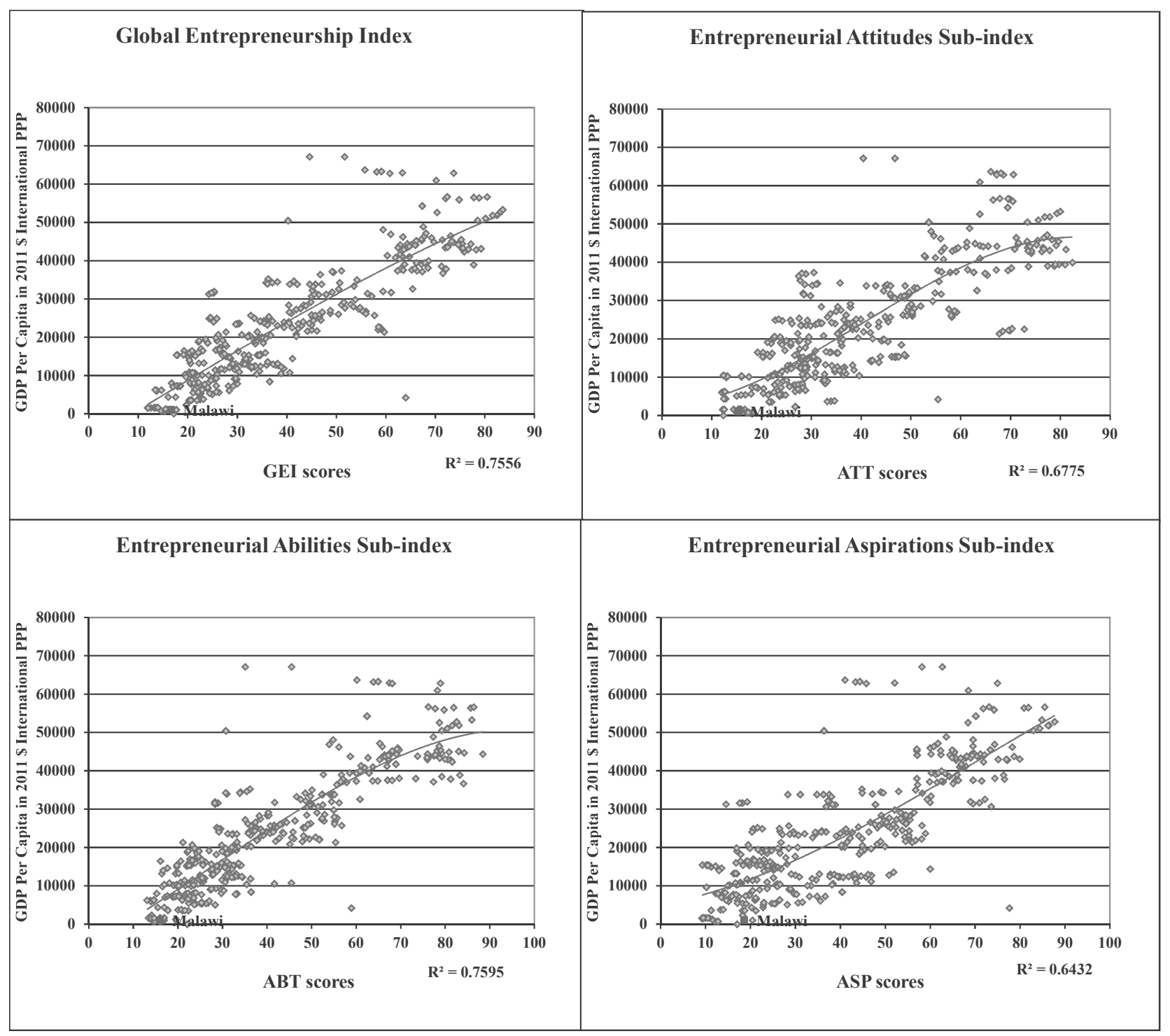

The first thing that we observe on the graphs is a strong positive coefficient of determination $\left(\mathrm{R}^{2}\right)$ in all the graphs at the global level, proving claims by Aljarwan et al. (2019) that entrepreneurial ecosystems are critical components of economic success. The Malawian eco-system shows weak performance on all the three subindices and GEI. In all the graphs, Malawi's performance falls below the global trendline. This implies that the contribution of Malawi's entrepreneurship (high TEA) to the economy is insignificant and does not contribute significantly to economic development, a common phenomenon among developing economies (Lafuente et al., 2018). Thus, a weak entrepreneurial ecosystem in Malawi has seen a limited impact of entrepreneurial pursuits on economic success as evidenced by very low GDP per capita. In this kind of environment, innovative entrepreneurship cannot thrive. 


\section{Malawi's entrepreneurship performance vis-à-vis the rest of the continent}

As shown in

Table1, Malawi (highlighted) has a GEI score of 12.2 which ranks it $133^{\text {rd }}$ among the 137 countries covered, outperforming only Burundi, Mauritania, and Chad in Africa. It records 15.3, 16, and 18.6 (out of a possible 100) for the attitude, ability, and aspiration sub-indices respectively. Botswana is the African country with the highest lead in attitude sub-index with a score of 46.9. Botswana ranks $52^{\text {nd }}$ among the 137 countries analysed in the GEI and ranks $1^{\text {st }}$ in Africa with a GEI of 34.9. South Africa on the other hand has a significant lead on the aspiration sub-index among the African countries with a score of 39.9. Again, South Africa has a significant lead on the ability sub-index with a score of 32.7. At the continental level, Africa records an average performance below 20 on all the three sub-indices and GEI with aspirations showing the lowest average score of 16.8 and attitudes showing the highest average score of 19.3

Table1: GEI ranking of African countries

\begin{tabular}{|ccllll|}
\hline GEI position & Country & ATT & ABT & ASP & GEI score \\
\hline 52 & Botswana & 46.9 & 32.4 & 23.8 & 34.9 \\
\hline 57 & South Africa & 27.7 & 32.7 & 39.9 & 32.9 \\
\hline 61 & Namibia & 32.4 & 27.2 & 28.6 & 31.1 \\
\hline 65 & Morocco & 27.3 & 22.4 & 34.8 & 29.7 \\
\hline 76 & Egypt & 17.5 & 21.6 & 33.5 & 25.9 \\
\hline 79 & Gabon & 24.1 & 20.1 & 23.4 & 25 \\
\hline 80 & Algeria & 30.9 & 19.5 & 16.3 & 24.7 \\
\hline 91 & Rwanda & 28.4 & 20.8 & 14.7 & 21.5 \\
\hline 93 & Ghana & 34 & 20.1 & 13.4 & 21.2 \\
\hline 101 & Nigeria & 24.2 & 23.6 & 18.3 & 19.7 \\
\hline 102 & Zambia & 21.5 & 21 & 18.2 & 19.6 \\
\hline 103 & Senegal & 26.8 & 14.1 & 18.3 & 19.2 \\
\hline 104 & Libya & 12.2 & 22.1 & 17 & 18.9 \\
\hline 105 & Cote d'Ivoire & 21.4 & 14.3 & 14.3 & 18.9 \\
\hline 109 & Kenya & 14.2 & 17.9 & 17.5 & 18.4 \\
\hline 110 & Ethiopia & 15.5 & 19.6 & 11.5 & 18.3 \\
\hline 115 & Tanzania & 15 & 18.2 & 11.9 & 16.4 \\
\hline 117 & Gambia & 16.1 & 15.8 & 14.5 & 16.1 \\
\hline 118 & Mali & 17.2 & 14.8 & 14.3 & 15.9 \\
\hline
\end{tabular}




\begin{tabular}{|llllll|}
\hline 119 & Liberia & 16.9 & 15.4 & 14.5 & 15.7 \\
\hline 121 & Cameroon & 17.5 & 15.8 & 12.7 & 15.4 \\
\hline 123 & Angola & 12.4 & 13.8 & 15.1 & 14.4 \\
\hline 124 & Mozambique & 13.4 & 13.5 & 14.2 & 14 \\
\hline 125 & Madagascar & 12.1 & 13.7 & 13.4 & 14 \\
\hline 128 & Benin & 13.3 & 12.4 & 11.9 & 13.3 \\
\hline 129 & Burkina Faso & 14.4 & 13.6 & 9.5 & 13.2 \\
\hline 130 & Guinea & 11.3 & 14.5 & 11.3 & 12.9 \\
\hline 131 & Uganda & 15.8 & 16 & 10 & 12.9 \\
\hline 132 & Sierra Leone & 10.6 & 12.5 & 10.9 & 12.3 \\
\hline 133 & Malawi & 15.3 & 16 & 18.6 & 12.2 \\
\hline 135 & Burundi & 8.9 & 15.2 & 9.9 & 11.8 \\
\hline 136 & Mauritania & 14.1 & 9.1 & 8.9 & 10.9 \\
\hline 137 & Chad & 7.9 & 9 & 9.2 & 9 \\
\hline Average scores & 19.3 & 17.8 & 16.8 & 18.5 \\
\hline
\end{tabular}

\section{Strengths and weaknesses of Malawi's entrepreneurial ecosystem}

Malawi's entrepreneurial ecosystem is generally weak. The entrepreneurial aspiration sub-index is the highest performing composite construct, meaning that Malawians have a greater entrepreneurial ambition despite their subdued perception of the potential for growth of start-ups (entrepreneurial ability) and attitude towards entrepreneurship.

\section{Entrepreneurial attitudes}

Start-up skills, risk acceptance, and networking are the worst-performing pillars under entrepreneurial attitude reporting scores of $0.01,0.03$, and 0.11 respectively. However, Malawians have a relatively high opportunity perception (0.40) and moderate cultural support (0.33). Approximately $33 \%$ of the population has a positive perception of entrepreneurship, while skills to start a business are perceived very negatively. There is also evidence that the population is overly risk-averse. Overall, negative attitudes are detrimental to entrepreneurial development in the country.

Table 2: Malawi's overall GEI score

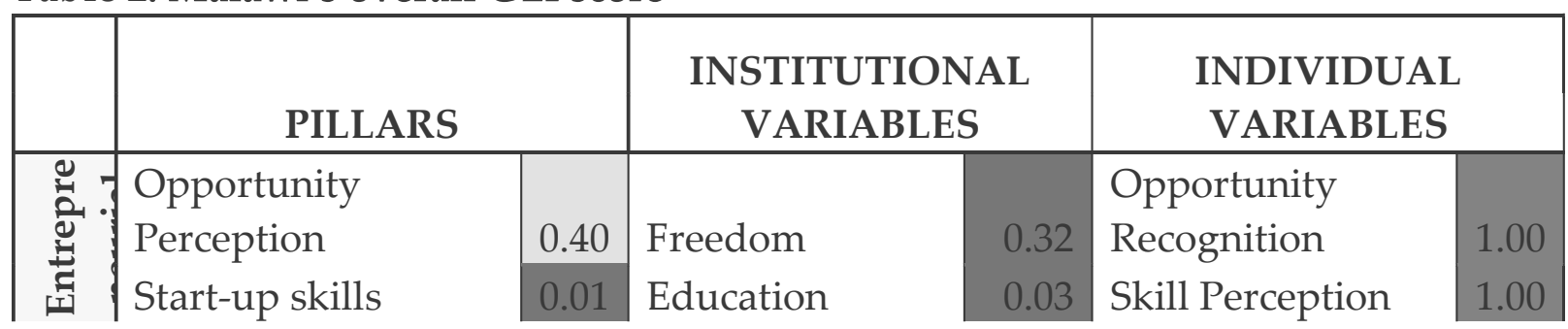




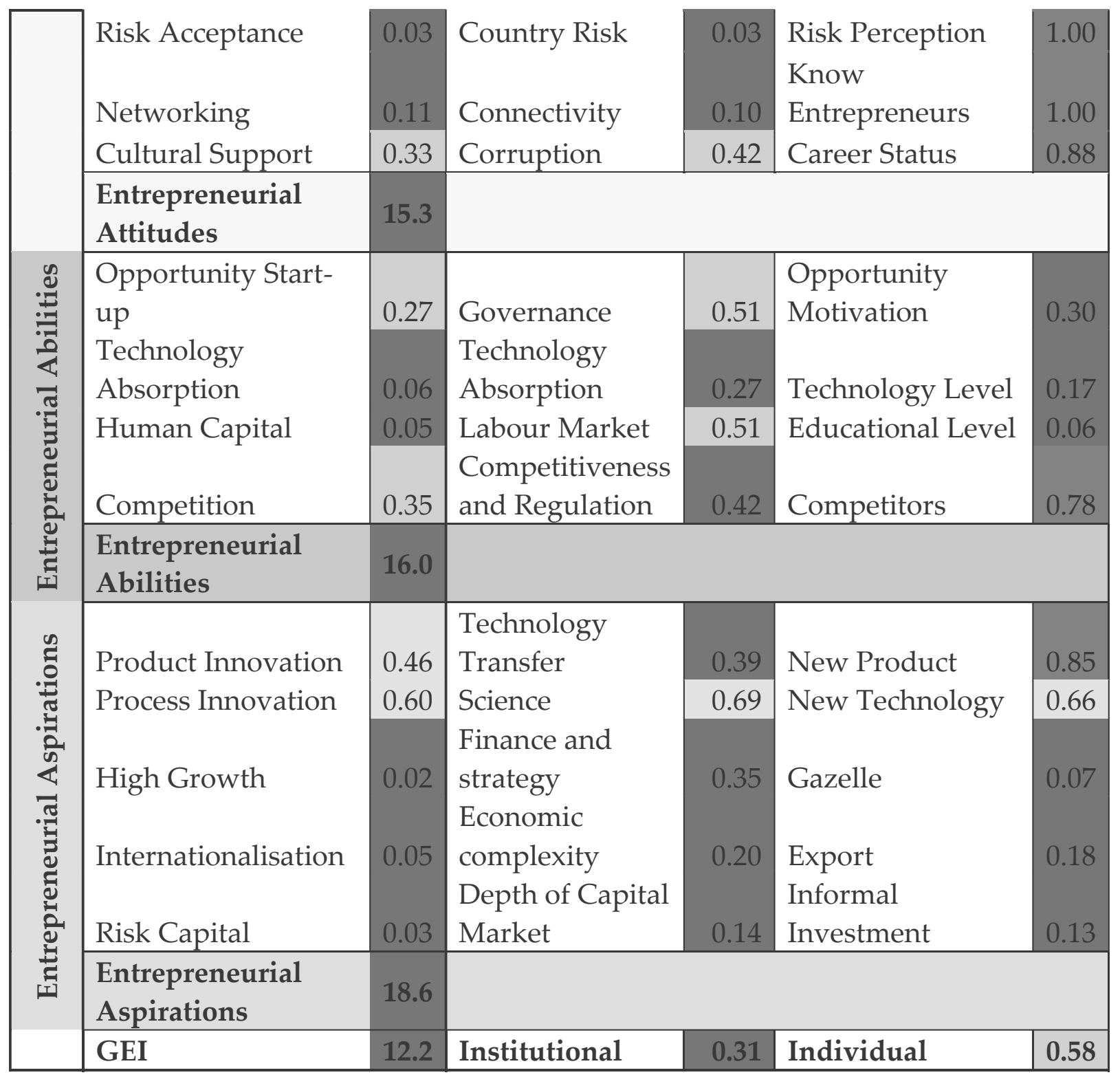

Poor quality education leads to weak human resources evidenced by a perception that only $1 \%$ of the population has the start-up skills needed by entrepreneurs. And this is woefully inadequate for a country that would want to make significant strides in entrepreneurship. Furthermore, the low score for risk acceptance perhaps may emanate from inadequate if not lack of proper financial information from the various corporate bodies within the country. Its score shows that only 0.03 out of 1 think that the fear of risk will not prevent them from becoming entrepreneurs. Most nascent entrepreneurs may need a large sum of money to operationalize their entrepreneurial ideas. However, the lack of sufficient financial protection from the country for creditors may dampen the creditors' desire to extend their credit facilities to nascent entrepreneurs. Commercial banks are naturally risk-averse to start-up lending. A 
networking score of 0.11 means that 0.11 out of 1 entrepreneur possess the know-how to create synergies with a business partner who has the same or similar business ideas. This could be due to the lack of business exposure at both the local and international levels and perhaps, the benefits that come with using the internet to create and maintain business relationships have not been embraced by the masses in Malawi. The use of networks in entrepreneurship cannot be overemphasised. According to Bosma and Schutjens (2011), the existence of entrepreneurial networks tends to boost the confidence of entrepreneurs in their capabilities. At the institutional level, Malawi is perceived positively on matters of corruption.

\section{Entrepreneurial ability}

Under this sub-index, the level of technology absorption and human capital pillars record very weak scores of 0.06 and 0.05 respectively. The technology absorption pillar represents how technologically inclined a country is and its readiness to augment its entrepreneurial activities with technology. The low level of technology absorption reveals that the economy of Malawi is not technologically driven nor enabled. Owing to Malawi's many necessity entrepreneurs compared to innovative entrepreneurs, the perceived usefulness of technology in facilitating growth-oriented entrepreneurship is low. Given the advancement of technology and its power to facilitate business, not harnessing its benefits only means Malawi and its entrepreneurs are left behind the rest of the world. It, therefore, comes as no surprise that Malawi is ranked 133rd in the GEI world rankings. Also, the poor human capital (0.05) is reflective of the fact that most of Malawi's entrepreneurs are not educated beyond high secondary school education and the perception of poor-quality education. Neither are there enough training avenues for both students and staff to enhance their creativity to become innovative entrepreneurs. The result is a low quality of entrepreneurship. However, there is also evidence that Malawi is relatively strong when it comes to governance while the country's labour market is also considered to be robust. These factors provide the opportunity to build on for better and stronger institutions.

\section{Entrepreneurial aspirations}

The entrepreneurial aspiration sub-index shows the process innovation pillar $(0.60)$ as the strongest pillar followed by product innovation (0.46). This is somewhat surprising because the process and product innovation rely greatly on technology however the technology absorption pillar is one of the weakest in the Malawian entrepreneurial ecosystem. Perhaps the entrepreneurs in Malawi have a great ambition to create new products and a good value chain. However, the lack of appropriate technology to support these ambitions makes its realisation far-fetched. It is also possible that the creation of new products is supported by rudimentary 
home-grown processes that use little technology. On the other hand, a paltry 0.02 score of "high growth" pillar implies that only about $2 \%$ of Malawian entrepreneurs desire high growth, revealing high levels of pessimism on the creation of a new and innovative business. The presence of Malawian entrepreneurs in the international market is also low with an internationalisation score of 0.05 out of 1 . Ironically, the high product development (0.85) and application of new technology (0.66) do not induce the expected rapid growth associated with innovation (gazelle $=0.07$ ). This is perhaps more telling of how weak and wasteful the Malawian ecosystem is. Risk capital is another weak performing pillar with a low score of 0.03 , which could be another explanator for low performance on internationalisation

\section{Conclusions}

This paper analysed the Malawian entrepreneurial ecosystem using the Global Entrepreneurship Index to ascertain the current state of entrepreneurship in Malawi. Further, the pillars within the GEI that required urgent policy intervention were identified. Malawi sits on the 133rd place on the GEI world ranking making it one of the poorest performers on entrepreneurship globally. The analysis further revealed that for a 0.02 increment in GEI score for Malawi, the government must intervene by putting in resources and drafting policies that address the bottleneck pillars that include start-up skills, risk acceptance, risk capital, high growth, and human capital. Government intervention that will improve the quality of education and enlighten Malawians on the economic benefits of innovative entrepreneurship cannot be overemphasised. There is also the need to educate Malawians on risk acceptance in business to reduce the fear of failure on entrepreneurial action. The analysis further revealed the lack of venture capital to be partly responsible for the poor performance of Malawi concerning entrepreneurial actions. The government should consider development financing and partner with the financial sector to facilitate venture capital for entrepreneurial growth.

\section{Policy recommendations}

The study also undertook a policy analysis to identify the bottlenecks in the ecosystem that required urgent attention and significant resources. The proposed policy interventions to improve Malawi's GEI by 0.02 are summarised in

Table 3. In total, five areas need policy attention.

Table 3: Policy Intervention

Pillar

Required Increase

in Pillar

Opportunity Perception
0.00
Percentage of

total new effort

$0 \%$ 
Start-up Skills

Risk Acceptance

Networking

Cultural Support

Opportunity Start-up

Technology Absorption

Human Capital

Competition

Product Innovation

Process Innovation

High Growth

Internationalisation

Risk Capital

\begin{tabular}{|cc|}
\hline 0.05 & $33 \%$ \\
\hline 0.03 & $20 \%$ \\
\hline 0.00 & $0 \%$ \\
0.00 & $0 \%$ \\
0.00 & $0 \%$ \\
0.00 & $0 \%$ \\
\hline 0.01 & $7 \%$ \\
\hline 0.00 & $0 \%$ \\
0.00 & $0 \%$ \\
0.00 & $0 \%$ \\
\hline 0.03 & $20 \%$ \\
\hline 0.00 & $0 \%$ \\
\hline 0.03 & $20 \%$ \\
\hline
\end{tabular}

Improvement of start-up skills requires the most resources, demanding a new effort of $33 \%$ to be made by the government. This means the government of Malawi must invest more in quality education in general and more specifically to increase the knowledge of Malawians on entrepreneurship and innovation. To improve risk acceptance, a new effort of $20 \%$ is needed. The government through its business development sector must educate its people on risk acceptance in business as a means to alleviate the inhibiting effect of fear of failure on entrepreneurial action. Improvement of entrepreneurship abilities will give entrepreneurs more confidence to exploit opportunities. On the other hand, strengthening capital markets through reforms and government credit guarantees may come in handy. A further $20 \%$ effort is needed to increase high growth by 0.03 . Moreover, the availability of venture capital is critical for entrepreneurial growth while the Malawian government needs to facilitate access to international markets. There is also a need to solve the high new product development-high adoption of new technology but the slow growth paradox. This may lead to major breakthroughs. Government and entrepreneurs must make it a point to inculcate the sophisticated business strategy of well-performing entrepreneurs into their operation as it can help boost entrepreneurial operations. Also, an effort of $20 \%$ is required to improve risk capital by 0.03 . Policies to boost and secure investor confidence in entrepreneurial activities in Malawi is needed so that investors can release more capital to expand entrepreneurial businesses in Malawi. The least effort of $7 \%$ is required to enhance the human capital pillar. Human capital development efforts should be aligned with the country's current and future needs. Invariably, training by corporates should be incentivised by among other things, tax benefits so employers may invest in training even with constrained resources. An example in this case is the Training Levy administered by the Human Resources 
Development Council of Botswana where companies contributing to the levy can claim training costs for their employees. It has to be noted that GEI is only a tool that is also not prescriptive. Therefore, to successfully build an efficient entrepreneurial ecosystem an in-depth engagement with local policymakers and implementers is ideal (Acs, et al., 2016; Szerb, Komlósi, and Páger, 2016). In the end, the most critical recommendation is for Malawi to adopt an entrepreneurial ecosystem approach in its economic policy development.

\section{References}

Ács, Z.J., Szerb, L., Autio, E. \& Lloyd, A. (2017). The Global Entrepreneurship Index. The Global Entrepreneurship and Development Institute, Washington, D.C., USA.

Aljarwan, A.A., Yahya, B.A., Almarzooqi, B.M. \& Mezher, T., 2019. Examining the framework of entrepreneurial ecosystems: A case study on the United Arab Emirates. International Journal of Entrepreneurship, 23(3), pp.1-16.

Audretsch, D.B., Carree, M.A., Van Stel, A.J. and Thurik, A.R., 2002. Impeded industrial restructuring: the growth penalty. Kyklos, 55(1), pp.81-98.

Beugelsdijk, S., \& Noorderhaven, N. (2004). Entrepreneurial attitude and economic growth: A cross-section of 54 regions. The Annals of Regional Science, 38(2), pp.199-218.

Bosma, N., \& Schutjens, V. (2011). Understanding regional variation in entrepreneurial activity and entrepreneurial attitude in Europe. The Annals of regional science, 47(3), pp.711-742.

Boston University School of Medicine. Theory of Planned Behaviour. https://sphweb.bumc.bu.edu/otlt/mphmodules/sb/behavioralchangetheories/BehavioralChangeTheories3.html.

Bullough, A., \& Renko, M. (2013). Entrepreneurial resilience during challenging times. Business Horizons, 56(3), pp.343-350.

Draghici, A., Albulescu, C. T., \& Tamasila, M. (2014). Entrepreneurial attitude as knowledge asset: its impact on the entrepreneurial activity in Europe. Procedia-Social and Behavioral Sciences, 109, pp.205-209.

Henley, A. (2007). Entrepreneurial aspiration and transition into self-employment: evidence from British longitudinal data. Entrepreneurship \& Regional Development, 19(3), pp.253-280.

Hessels, J., van Gelderen, M., \& Thurik, R. (2008). Drivers of entrepreneurial aspirations at the country level: the role of start-up motivations and social security. International Entrepreneurship and Management Journal, 4(4), pp.401417. 
Jayeoba, F. I. (2015). Entrepreneurial intention and entrepreneurial abilities. IFE PsychologIA . An International Journal, 23(1), pp.219-229.

Karlsson, T., \& Moberg, K. (2013). Improving perceived entrepreneurial abilities through education: Exploratory testing of an entrepreneurial self efficacy scale in a pre-post setting. The International Journal of Management Education, 11(1), pp.1-11.

Lee, J. H., \& Venkataraman, S. (2006). Aspirations, market offerings, and the pursuit of entrepreneurial opportunities. Journal of Business Venturing, 21(1), 107-123.

Ndala, N. N \& Pelser, T. (2019). Examining the Effectiveness of Entrepreneurship Policy Implementation in Malawi. Journal of Contemporary Management, 16, pp.234-255.

Passafaro, P., Livi, S., \& Kosic, A. (2019). Local norms and the theory of planned behavior: Understanding the effects of spatial proximity on recycling intentions and self-reported behavior. Frontiers in psychology, 10, 744.

Räty, H., Komulainen, K., Hytti, U., Kasanen, K., Siivonen, P., \& Kozlinska, I. (2019). University students' perceptions of their abilities relate to their entrepreneurial intent. Journal of Applied Research in Higher Education, 11(4), pp.897-909.

Stam, E. (2015). Entrepreneurial ecosystems and regional policy: a sympathetic critique. European Planning Studies, 23(9), pp.1759-1769.

Szerb, L., \& Trumbull, W. (2018). Entrepreneurship development in Russia: Is Russia a normal country? An empirical analysis. Journal of Small Business and Enterprise Development, 25(6), pp.902-929.

Szerb, L., Komlósi, É. \& Páger, B. (2016). Measuring Entrepreneurship and Optimizing Entrepreneurship Policy Efforts in the European Union. CESifo DICE Report, ISSN 1613-6373, ifo Institut - Leibniz-Institut für Wirtschaftsforschung an der Universitat München, München, 14(3), pp.8-23. Van Stel, A., Carree, M., \& Thurik, R. (2005). The Effect of Entrepreneurial Activity on National Economic Growth. Small Business Economics, 24(3), pp.311-321.

World Bank (2020). Ease of doing business. https://www.doingbusiness.org/en/rankings. 